\title{
NAPROXEN INDUCED ERYTHEMA MULTIFORME-A RARE CASE REPORT
}

Case Study

\author{
SAI KEERTHANA P. C. ${ }^{1}$, ANILA K. N. ${ }^{2 *}$, RESHMA REJI ${ }^{1}$
}

1Pharm D, 2Lecturer Department of Pharmacy Practice, Amrita School of Pharmacy, Kochi, Amrita Vishwa Vidyapeetham, Amrita University, India

Email: anilakn@aims.amrita.edu

Received: 24 Feb 2016 Revised and Accepted: 09 Jan 2017

\begin{abstract}
Erythema multiforme (EM) is a hypersensitivity reaction characterized by varying degrees of blisters and ulcerations. We report a case of 4 y old girl child born for Non-custodial parents who has a history of seizures and a known case of carbamazepine-induced SLE (Systemic Lupus Erythematosus) when treated with anti-inflammatory drugs developed EM. The offending drug was identified and withdrawn. Steroid was given as a part of symptomatic treatment. Non-steroidal anti-inflammatory drugs (NSAIDs) are one of the most commonly prescribed groups of drugs for a variety of indications. The patient gradually improved and got discharged.
\end{abstract}

Keywords: Erythema Multiforme, Naproxen, Hypersensitivity, Skin Disorders

(c) 2016 The Authors. Published by Innovare Academic Sciences Pvt Ltd. This is an open access article under the CC BY license (http://creativecommons.org/licenses/by/4. 0/) DOI: http://dx.doi.org/10.22159/ijpps.2017v9i3.14903

\section{INTRODUCTION}

Erythema Multiforme (EM) is an acute mucocutaneous inflammatory and hypersensitivity reaction characterized by skin eruption, with symmetric erythematous edematous or bullous lesion of the skin or mucous membrane. More than half of the cases are caused by medications or immunotherapy [1]. Erythema multiforme commonly affects young age groups. However, all age groups can be affected.

Typically in Erythema Multiforme, few to hundreds of skin lesion erupts with $24 \mathrm{~h}$. The lesions are first seen on the back of hands or top of feet and then spread along the limbs and trunk. The upper limbs are mostly affected. There may be itching and burning sensation. The initial lesions are sharply demarcated, round, $\mathrm{red} / \mathrm{pink}$ and flat and gradually enlarge to form plaques. Lesions

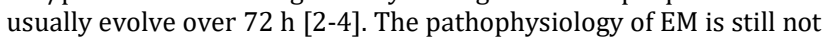
completely understood, but it is probably immunologically mediated. Culprit drugs are antibiotics, anticonvulsants, and NSAIDS. Sulfa drugs are the most common triggers. Herpes infection is the most common infection which causes EM. A full skin examination is required for differential diagnosis with other skin disorders.

The treatment is usually symptomatic. The cause should be identified at most early if a drug is suspected and it must be withdrawn as soon as possible. This includes all medications begun during the preceding 2 mo. Studies have shown that prompt withdrawal of causative drugs will reduce the risk of death by about $30 \%$ [5-9]. Herein we discuss a case of NSAID-induced EM.

\section{CASE REPORT}

A 4 y old girl with normal birth and developmental history born to a NCP parents, has a history of seizures from 3year of age with complex partial seizure semiology on medication Tegretol (carbamazepine) and Frisium (clobazam) started 10 mo back. She had joint pain and rash during last 5 mo which was evaluated in February 2016 and diagnosed as drug induced SLE (carbamazepine). Carbamazepine was stopped, and a dose of Frisium was hiked. The ANA profile was positive, anti-histones were also positive. Pediatric Rheumatology confirmed the case to be SLE with its systemic complication (Lupus Arthritis). She was treated accordingly and discharged with Tab hydroxychloroquine $100 \mathrm{mg}$ OD and Tab naproxen $250 \mathrm{mg} 1 / 2$ TID. After 3days she again got admitted with rashes in the forearms and recurrent episodes of seizures. On examination her vitals where stable, no lateralizing neurological signs, Koebner Phenomenon was positive. She was loaded with Inj. leviteracetam (Levipil) $1 \mathrm{~g}$ and she had further events during which dose of Levipil was hiked. Her $24 \mathrm{~h}$ VEEG done showed Left Focal seizures. She was given inj lorazepam $2 \mathrm{mg}$ stat and shifted to ICU for further monitoring. She had skin rashes during admission for which dermatology consultation was taken and confirmed to be Erythema Multiforme. Due to increased possibility of NSAIDS induced skin disorders, dermatologists advised to stop Tab. naproxen and to add prednisolone $5 \mathrm{mg}$ OD, Tab topiramate 25 $\mathrm{mg} 1 / 2 \mathrm{BD}$ was also added. No other antiseizure drugs could be added due to the possibility of HLA-B activation. After $2 \mathrm{~d}$ she had a reduction in seizures and no new skin lesions. She was discharged with advice to review, and the parents were well explained about nature of the illness.

\section{DISCUSSION}

Erythema Multiforme is an acute, sometimes recurrent mucocutaneous condition of uncertain etiopathogenesis that can follow the administration of drugs or infections. Identification of cause is very important. Treatment of Erythema Multiforme depends on the severity of clinical features. Steroids and antihistamines are used as a part of treatment [10-12]. If it is HSV related, then antivirals will be used. Recurrences are seen in 20-25\% cases. Antibiotics and NSAIDS are the most common groups of drugs causing EM [13]. In this case, we used Naranjo probability ADR scale for causality assessment and was found to have a score of 8 (probable). Re challenge was not performed due to inherent risk [14-17]. Differential diagnosis from other skin diseases and withdrawal of offending agents at the right time will decrease the mortality rate.

\section{CONCLUSION}

An important step in the management of EM is prompt recognition and withdrawal or prevention of contact with a causative agent. Here naproxen was discontinued and provided timely management with corticosteroids. Clinicians and clinical pharmacist should pay kind attention in such cases to also educate patients and their caretakers in recognising and reporting the occurrences of any side effects. Patient/Bystander was also informed about the condition and chances for recurrences of skin reactions.

\section{ACKNOWLEDGMENT}

First and foremost, I thank god and my parents giving me strength and courage to aspire my aims. Then I would like to thank Mrs. Anila KN lecturer, Dept. of pharmacy practice, without whose guidance and support, reporting of this adverse effect would not have been possible. 


\section{CONFLICT OF INTERESTS}

Declared none

\section{REFERENCES}

1. Wallace JL. Nonsteroidal anti-inflammatory drugs and gastroenteropathy: the second hundred years. Gastroenterology 1997;112:1000

2. Erythema Multiforme: In: Dermatology Lecture notes-Cairo University. Available from: http://www.medicine.cu.edu.eg/ beta/index.php/en/departments/46-microbiology36/169ssss44. [Last accessed on 02 Jul 2016]

3. Erythema Multiforme: In: Dermatology Lecture notes-Cairo University. Available from: http://www.medicine.cu.edu.eg/ beta/index.php/en/departments/46-microbiology36/169ssss44. [Last accessed on 02 Jul 2016]

4. Cullen D, Bardhan KD, Eisner M. Primary gastroduodenal prophylaxis with omeprazole for non-steroidal antiinflammatory drug users. Aliment Pharmacol Ther 1998;12:135.

5. Roujeau JC, Stern RS. Medical progress: severe adverse cutaneous reactions to drugs. N Engl J Med 1994;331:1272-85.

6. Carder RK. Hypersensitivity reactions in neonates and infants. Dermatol Ther 2005;18:160-75.

7. Farthing P, Bagan JV, Scully C. Mucosal disease series. Number IV. Erythema multiforme. Oral Dis 2005;11:261-7.

8. Zohdi-Mofi dM, Horn TD. The acrosyringeal concentration of necrotic keratinocytes in erythema multiforme: a clue to drug etiology. Clinicopathologic review of 29 cases. J Cutan Pathol 1997;24:235-40.
9. Karakaya G, Sahin S, Kalyoncu AF. Erythema multiforme: as a complication of allergen-specific immunotherapy. Allergol Immunopathol (Madr) 2001;29:276-8.

10. Prieto A, De Barrio M, Pérez C, Vellosa A, Baeza ML, Herrero T. Piroxicam induced erythema multiforme. Contact Dermatitis 2005;53:263.

11. Shopf E. Skin reactions to co-trimoxazole. Infection 1987;15 Suppl 5:S254-8.

12. Katoh N, Kagawa K, Yasuno H. Piroxicam induced StevensJohnson syndrome. J Dermatol 1995;22:677-80.

13. Hallgren J, Tengvall-Linder $\mathrm{M}$, Persson $\mathrm{M}$, Wahlgren $\mathrm{CF}$. Stevens-Johnson syndrome associated with ciprofloxacin: a review of adverse cutaneous events reported in Sweden as associated with this drug. J Am Acad Dermatol 2003;49(5 Suppl):S267-9.

14. Pise HN, Padwal SL. Diclofenac-induced angioedema: a case report. Asian J Pharm Clin Res 2015;8;4-5.

15. Campi P, Pichler WJ. Quinolone hypersensitivity. Curr Opin Allergy Clin Immunol 2003;3:275-81.

16. Gonzalez I, Lobera T, Blasco A, Del Pozo MD. Immediate hypersensitivity to quinolones; moxifl oxacin cross-reactivity. J Invest Allergol Clin Immunol 2005;15:146-9.

17. Schmid DA, Depta JPH, Pichler WJ. T cell-mediated hypersensitivity to quinolones: mechanisms and crossreactivity. Clin Exp Allergy 2006;36:59-69.

\section{How to cite this article}

- Sai Keerthana PC, Anila KN, Reshma Reji. Naproxen-induced erythema multiforme-a rare case report. Int J Pharm Pharm Sci 2017;9(3):294-295. 